\title{
Changes in light absorption by the chloroplast, related to its structural transformations*
}

\author{
J. ZURZYCKI AND H. GABRYS \\ Department of Plant Physiology, Institute of Molecular Biology, \\ Jagiellonian University
}

(Received: March 14, 1977)

\begin{abstract}
The changes in light absorption of single chloroplasts and one layer of chloroplasts related to their structural transformations were considered. Theoretical calculations of light absorption $\left(\mathrm{E}_{\mathrm{A}}\right)$ and transmission $\left(\mathrm{E}_{\mathrm{T}}\right)$ as well as for the mean intensity of absorption $\left(\overline{\mathrm{I}}_{\mathrm{A}}\right)$ for the ellipsoid of revolution were given by the formulas 3,2 and 1 respectively.

It was shown that the true shape of Funaria chloroplasts can be considered as ellipsoid of revolution. From the four conformational states of chloroplasts the most flattened one (corresponding to the low intensity of illumination) absorbs maximal amount of light energy. For the one layer of chloroplasts the changes in light absorption connected with structural transformations were estimated as ca. $4 \%$.
\end{abstract}

\section{INTRODUCTION}

Leaves can be observed to demonstrate rather quick and reversible changes in absorption of light. Comparatively extensive changes ranging from a few to a dozen or so per cent of the initial absorption value, accompany morphological transformations of the photosynthetic apparatus, i.e. they are related with alternations in the shape and volume of the chloroplasts and with their displacement in the cell. The effect of translocation of the chloroplasts on absorption has been the subject of theoretical considerations ( $\mathrm{Zurzycki}, 1953$; Britz, 1975) as well as experimental measurements of changes in transformation of a leaf with the simultaneous control of chloroplast position (B i e bl, 1954; Z urzycki, 1961; $\mathrm{Pfa} u$ et al., 1974), changes in transmission being often regarded as a criterion of translocation (B i e b l, 1954; L e ch ow s k i, 1970, 1973; Inoue, Shibata, 1973; Pfau et al., 1974). However, the effect of

* This study was carried out under the project No 10.2.10 coordinated by Institute of Ecology, Polish Academy of Sciences. 
structural changes on absorption has been studied chiefly in suspension of chloroplasts (I to h et al., 1963, Y a m a s hit a et al., 1968), and therefore in a system of statistically random distribution of chloroplasts. Changes in leaf transmission analogous to those in transmission of a chloroplast suspension were regarded as a manifestation of structural transformations of the chloroplasts in vivo (P a c k e r et al., 1967; H e b e r 1969). However, the chloroplasts of the living cell are characterized by a definite and on the whole not accidental positioning. The object of the present investigation was to assess changes in absorption by an individual chloroplast of a specific position in relation to an incident beam of light during its structural transformations evoked by various conditions of illumination.

\section{METHOD}

The theoretical calculation of the absorption of radiation in a single chloroplast required the assumption of certain simplifications. Thus it was assumed that:

a) the chloroplast is an ellipsoid of revolution in shape,

b) total amount of pigments responsible for absorption remains unchanged during structural transformations,

c) these pigments are uniformly distributed throughout the chloroplast volume.

The validity of the first assumption was checked with two methods. The shapes of optical sections of chloroplasts obtained with the photographs of the chloroplasts of Funaria in profile position, taken using a $100 \times$ NA 1,25 objective, were compared with the theoretical shapes of corresponding ellipses. Besides this light transmission was measured locally for the chloroplasts in flat position at several points along their width and the results were compared with the theoretical local absorption for the ellipsoid of revolution.

On the basis of the above assumptions the equation was worked out which determined the absorption of radiation by the chloroplast. For quantitative interpretation presented by way of example, the authors used model chloroplasts of Funaria hygrometrica for which mean changes in dimensions, dependent on the state of conformation had been determined in an earlier study ( $\mathrm{Zurzycki}$, 1975). In order to establish the initial absorption (yielding information of the amount of pigments), local measurements of light transmission were taken in the centre of the flatwise positioned chloroplast for three wavelengths: 450, 546 and $675 \mathrm{~nm}$. Isolation of monochromatic radiation was accomplished by means of Zeiss interference filters (Jena) of half-width 5,5 9,5 and 8,5 $\mathrm{nm}$ respectively. The microscope with a $100 \times$ NA 1,25 objective and a $10 \times$ eyepiece was illuminated with a lamp of stabilized voltage. There was an aperture (of the diameter corresponding to $1 \mu \mathrm{m}$ in the samle) in the plane of the 
image, through which the light reached the IP 22 (RCA) photomultiplier fed with the current of 0,9 to $1,25 \mathrm{kV}$. The photocurrent was read out on a Zeiss scale galvanometer. Measurements were performed on the chloroplasts lying flatwise and adapted to darkness. A readout of transmission in the centre of the chloroplast was corrected by a reading of the "background", i.e. by the mean transmission at two opposite points lying outside the chloroplast but in its direct proximity. In the case of considerable divergences between the two readings of the background the measurement was discarded. The results are the means of the measurements of 20 chloroplasts for each wavelength.

The light absorption by the model chloroplast was calculated using a ODRA 1204 digital computer.

\section{RESULTS}

Ellipsoidal form of chloroplast section

The longer axis of the optical section of the chloroplast in profile position (Fig. 1a) was divided into ten equal sections. Thus the points separat-
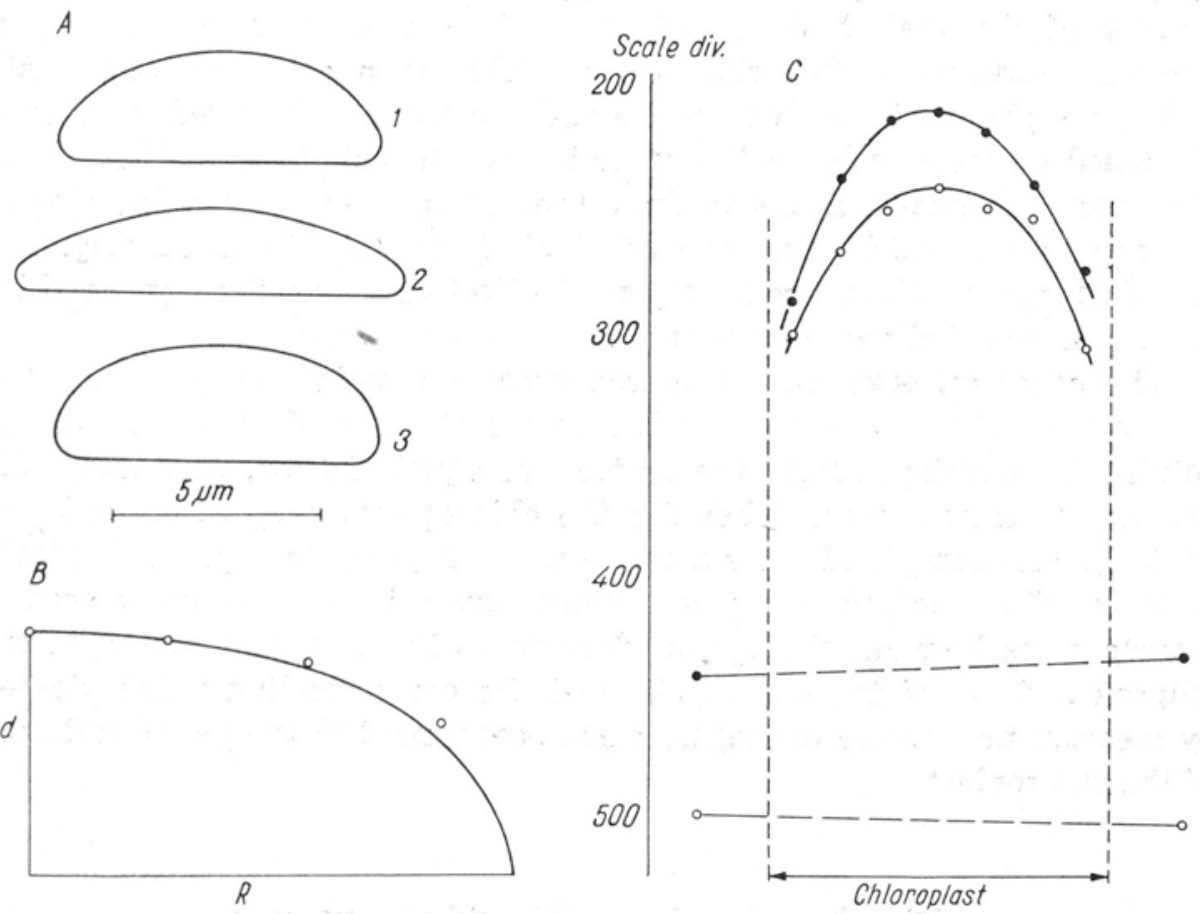

Fig. 1. A - Optical cross sections of chloroplasts of Funaria hygrometrica. 1-from darkness (state I) 2-from low light intensity (state II) 3-from very intense light (state IV)

B - Theoretical thickness of an ellipse and the thickness calculated from the local light absorption (points) C - Local absorption of chloroplast (examples of readings) 
Table 1

Elipse and chloroplast thickness at various distances from the centre

\begin{tabular}{|l|c|c|c|c|}
\hline $\begin{array}{c}\text { Distance } \\
\text { from the } \\
\text { centre (R) }\end{array}$ & Ellipse & State I & State II & State III \\
\hline & & 1 & 1 & 1 \\
\multicolumn{1}{c|}{0} & 1 & 1 & $0.9796 \pm 0.0051$ & $0.9765 \pm 0.0062$ \\
$1 / 5$ & 0.9798 & $0.9738 \pm 0.0026$ & $0.9303 \pm 0.0055$ & $0.9198 \pm 0.0137$ \\
$3 / 5$ & 0.9165 & $0.9149 \pm 0.0062$ & $0.8282 \pm 0.0087$ & $0.8164 \pm 0.0256$ \\
$4 / 5$ & 0.8000 & $0.8026 \pm 0.0145$ & $0.6587 \pm 0.0130$ & $0.6299 \pm 0.0214$ \\
$4,5 / 5$ & 0.6000 & $0.6216 \pm 0.0143$ & $0.6587 \pm 0.0199$ \\
\hline
\end{tabular}

ing these sections lay at the distances of $0,11 / 5 R, 2 / 5 R, 3 / 5 R$ and $4 / 5 R$ from the centre. For the ellipse, the lengths of the secants perpendicular to the longer axis and passing through the above points should be equal to $1,0.9798,0.9165,0.8$ and $0.6 \mathrm{~d}$. The real values of chloroplast thickness, which are means for 15 chloroplasts, are listed in Table I for three configural states. The results indicate a generally fairly high degree of conformity of the real thickness of chloroplasts with that of the ellipse. Greater discrepancies (the chloroplast thicker than expected) occur only on the periphery of the chloroplasts and are most pronounced in state II (flattened chloroplasts). On the other hand, the real shape of the chloroplast section deviates as a role from that of an ellipse, since the side of the chloroplast which faces the cell wall is usually flattened (Fig. 1a). This fact, nevertheless, has no essential effect on absorption by the chloroplast illuminated perpendicularly to its largest section.

The other criterion of shape was based on optical properties. Local absorption $\left(\mathrm{I}_{\mathrm{A}}\right)$ was measured in the centre of the chloroplast and at the points whose distance from the centre was equal to $2 / 7 R, 4 / 7 R$ and $6 / 7 R$. The measurements were taken for the chloroplasts adapted to darkness (state I). An example of these measurements is given in Fig. 1c. Similarly as in the first method, the mean results given in Fig. 1b. show certain discrepancies between the optical density obtained on assumption of the ellipsoidal form of the chloroplast and the corresponding value yielded by measurement, these divergences are pronounced in the peripheral area of the chloroplast.

\section{Light absorption in an ellipsoid of revolution}

Let us consider an ellipsoid of revolution, such as in Fig. 2, denoting its two longer semi-axes as $R$ and the shorter axis as $d$. Let this solid be illuminated with an incident beam of parallel light perpendicular to the largest section, i.e. to $F=\pi R^{2}$. In accordance with the assumptions, light 


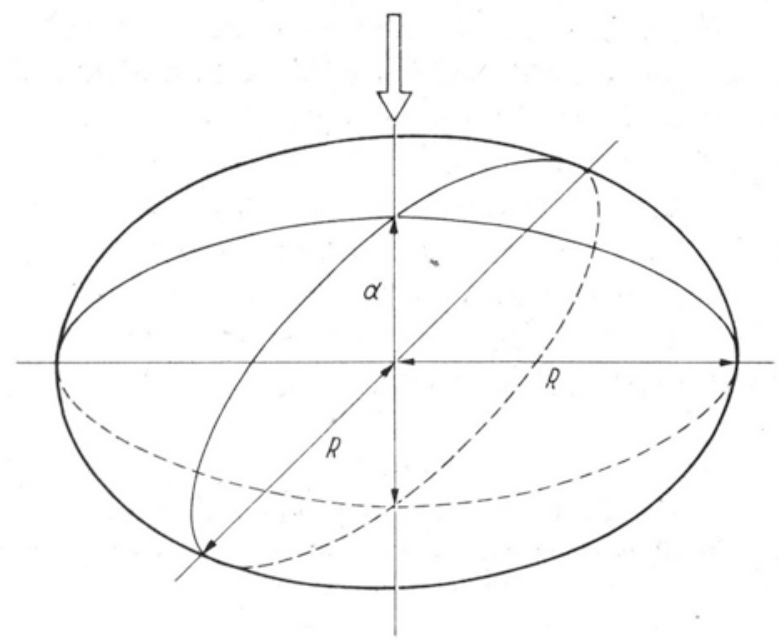

Fig. 2. Chloroplast as an ellipsoid of revolution

absorption follows Beer-Lambert's law. The energy transmitted by the ellipsoid amounts in this case (on application of Cartesian coordinates) to:

$$
E_{T}=4 I_{0} \int_{0}^{R} \int_{0}^{\sqrt{R^{2}-x^{2}}} e^{-2 x c} \frac{d}{R} \sqrt{R^{2}-x^{2}-y^{2}} d y d x
$$

where

$\mathrm{I}_{0}$ - intensity of incidenit light

$\alpha c$ - natural absorption coefficient

c - pigment concentration

$\alpha$ - specific absorption coefficient

hence the energy absorbed in ellipsoid $\mathrm{E}_{\mathrm{A}}$ is equal to:

$$
\mathrm{E}_{\mathrm{A}}=\mathrm{I}_{0} \mathrm{~F}\left[1-\frac{1}{2 \alpha^{2} \mathrm{c}^{2} \mathrm{~d}^{2}}\left\{1-(2 \alpha \mathrm{cd}+1) \mathrm{e}^{-2 \alpha \mathrm{cd}}\right\}\right]
$$

On the other hand, the mean intensity of absorbed light $\left(\bar{I}_{\mathrm{A}}\right)$ is as follows:

$$
\overline{\mathrm{I}}_{\mathrm{A}}=\mathrm{I}_{0}\left[1-\frac{1}{2 \alpha^{2} \mathrm{c}^{2} \mathrm{~d}^{2}}\left\{1-(2 \alpha \mathrm{cd}+1) \mathrm{e}^{-2 \alpha \mathrm{cd}}\right\}\right]
$$

Light absorption by the chloroplasts of Funaria hygrometrica in particular conformation states

The chloroplasts of Funaria were introduced as model chloroplasts for which the calculation of changes in absorption related with the altered state of conformation was performed, assuming that the local thickness of the chloroplasts was in accordance with the values obtained for the 
ellipsoid of revolution. In order to establish the natural absorption coefficient the authors performed a series of determinations of local absorption $\left(\mathrm{I}_{\mathrm{A}}\right)$ in the centre of the chloroplasts adapted to darkness, whose mean thickness at that point amounted to $3,3 \mu \mathrm{m}$. Mean per cent values of absorbed light (mean for 20 chloroplasts) and extreme values are presented in Table 2. In some further calculations the values of the natural absorption coefficient $(\alpha$ c) equal to $0,278,0,108$ and 0,032 were adopted, corresponding to local absorption in the centre of the chloroplast amounting to $60 \%, 30 \%$ and $10 \%$ respectively.

Table 2

Light absorption in the centre of chloroplast $\left(\mathrm{I}_{\mathrm{A}}\right)$ and ensuing coefficients of extinction. The data represent mean values for 20 measurements of the chloroplasts adapted to darkness, and extreme values (in brackets)

\begin{tabular}{|c|c|c|}
\hline Wavelenght & $\begin{array}{c}\mathrm{I}_{\mathrm{A}} \text { mean and extreme } \\
\text { values }(\%)\end{array}$ & $\alpha \mathrm{c}=2,303 \frac{\log \mathrm{I}_{\mathrm{o}} / \mathrm{I}_{\mathrm{T}}}{2 \overline{\mathrm{d}}}$ \\
\hline 450 & $61.16(47.5-81.1)$ & $0.287(0.195-0.505)$ \\
546 & $11.53(1.8-18.4)$ & $0.037(0.005-0.061)$ \\
675 & $54.43(41.5-68.4)$ & $0.238(0.163-0.349)$ \\
\hline
\end{tabular}

The chloroplast dimensions corresponding to four states of conformation were adopted on the basis of the earlier studies ( $\mathrm{Z} \mathrm{urzycki}, 1975)$ (Table 3).

Table 3

Relative dimensions of the chloroplasts of Funaria hygrometrica (Zurzycki 1975)

\begin{tabular}{|l|c|c|c|}
\hline \multicolumn{1}{|c|}{ State } & Sufrace F $\left(\mu \mathrm{m}^{2}\right)$ & Thickness d $(\mu \mathrm{m})$ & Volume V $\left(\mu \mathrm{m}^{3}\right)$ \\
\hline I & 51.8 & 3.30 & 114 \\
II & 67.4 & 1.96 & 88.1 \\
III & 44.9 & 2.78 & 83.3 \\
IV & 40.1 & 2.95 & 73.6 \\
\hline
\end{tabular}

Fig. 3 shows the correlation between the mean intensity of the light absorbed by the model chloroplast $\left(\overline{\mathrm{I}}_{\mathrm{A}}\right)$ and its surface. The mean intensities of the light of three wavelengths, absorbed by the chloroplast in four conformation states are compared in Table 4. It follows from this comparison that the lowest mean intensity of absorption occurs in the flattened chloroplasts (state II), whereas it is highest in chloroplasts in the state of strong contraction (state IV). However, this result is not essential for the consideration of energy, since it yields information of the mean intensity 
Table 4

Mean intensity of the light absorbed by chloroplast $\left(\overline{\mathrm{I}}_{\mathrm{A}}\right)$ in $\%$ for four conformation states and three wavelengths. Extreme values are given in brackets

\begin{tabular}{|l|c|c|c|}
\hline State & $450 \mathrm{~nm}$ & $546 \mathrm{~nm}$ & $675 \mathrm{~nm}$ \\
\hline I & $45.42(34.11-64.26)$ & $7.78(1.09-12.45)$ & $39.70(29.56-51.77)$ \\
II & $37.50(27.58-55.33)$ & $6.04(0.84-9.74)$ & $32.43(23.72-43.31)$ \\
III & $50.03(38.06-69.11)$ & $8.91(1.26-14.21)$ & $44.03(33.15-56.58)$ \\
IV & $53.79(41.39-72.65)$ & $9.92(1.41-15.76$ & $47.62(36.20-60.42)$ \\
\hline
\end{tabular}

of the absorbed radiation falling on the surface unit of the chloroplast, while it does not take into account simultaneous changes in the illuminated surface of the chloroplast. When these changes are taken into conside-

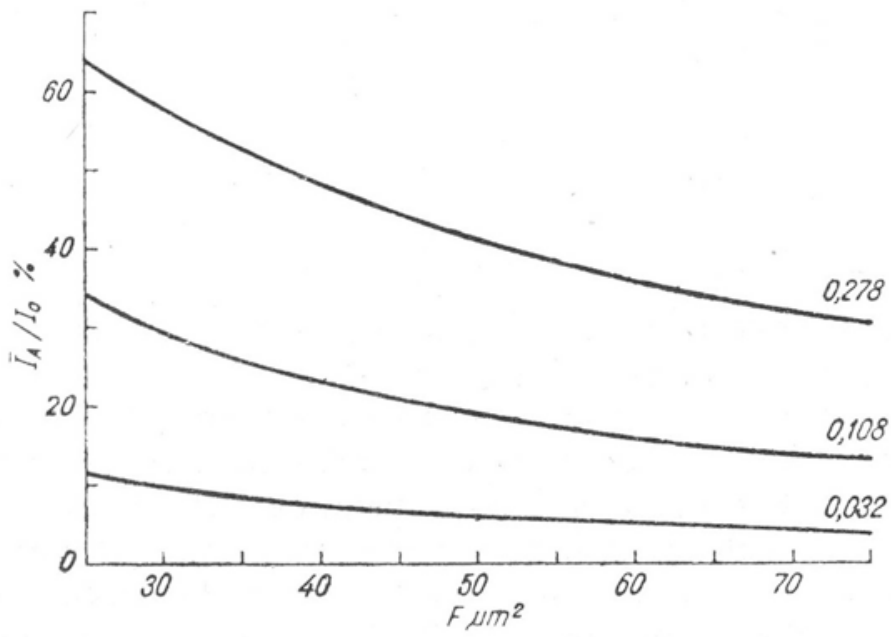

Fig. 3. Dependence of the mean absorption of light $\left(\overline{\mathrm{I}}_{\mathrm{A}}\right)$ (y axis) on the surface of chloroplast $\mathrm{F}(\times$ axis)

ration (by multiplying $\overline{\mathrm{I}}_{\mathrm{A}}$ by $\mathrm{F}$ ), a different picture is obtained. Table 5 shows relative changes in absorbed energy $\left(\mathrm{E}_{\mathrm{A}}\right)$ in particular conformation states as compared with the dark chloroplasts. It follows from this data that the flattened chloroplasts absorb most energy of the incident light, and those in the state of great contraction - the least amount of it. An example of the correlation between the absorbed energy and the surface of the model chloroplast is given for blue light in Fig. 4.

While analyzing the light energy absorbed by the whole cell, it should also be taken into account that part of the radiation by-passes the chloroplasts which do not cover the entire surface of the cell. This was done in the last version of calculations. Let us analyze a cell measuring 30 by $20 \mu \mathrm{m}\left(\mathrm{F}=600 \mu \mathrm{m}^{2}\right)$ exposed ito light of the intensity of 100 units per 
Table 5

Relative energy absorbed by chloroplast $\left(E_{A}\right)$, depending on its conformation state

\begin{tabular}{|l|c|c|c|}
\hline \multirow{2}{*}{ State } & \multicolumn{3}{|c|}{$\mathrm{E}_{\mathbf{A}}$-(relative units) } \\
\cline { 2 - 4 } \multicolumn{1}{|c|}{} & 450 & 546 & 675 \\
\hline I & 100 & 100 & 100 \\
II & 107.5 & 100.1 & 106.2 \\
III & 95.5 & 98.9 & 96.1 \\
IV & 91.7 & 98.3 & 92.8 \\
\hline
\end{tabular}

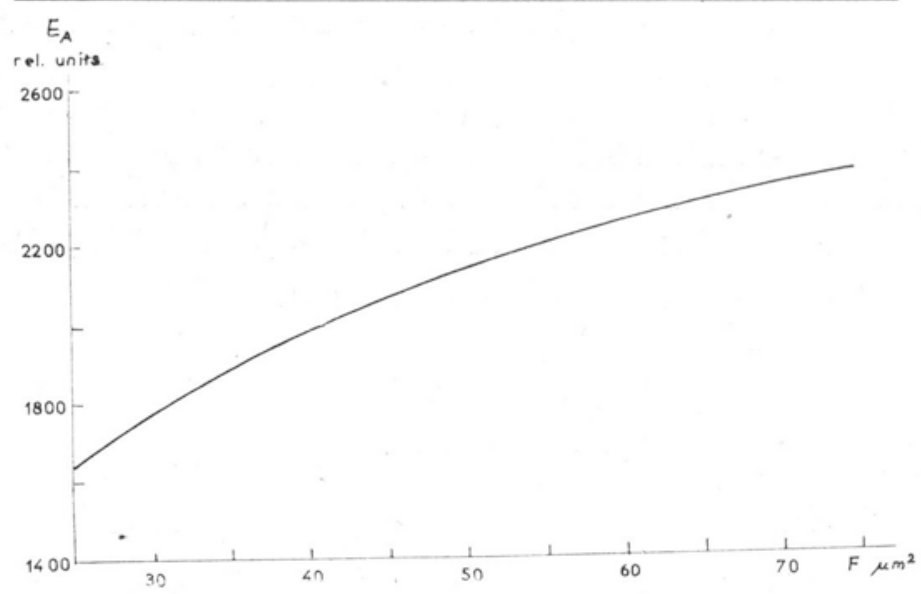

Fig. 4. Dependence of the absorbed light energy (in relative units) (y axis) on the surface of chloroplast $(X$ axis)

$\mu \mathrm{m}^{2}$. Let us consider one layer of the chloroplasts which in the initial state covers $90 \%$ of the surface of the illuminated cell wall, forming a kind of mosaic on it. Furthermore, let us assume that with the change of external conditions the chloroplasts do not alter their position, only undergoing typical structural changes. Then the energy of the radiation absorbed by the cell is the highest in state II of the chloroplasts, amounting to $33,7 \%$ and diminishes to $27,98 \%$ in the state of strong contraction (Table 6 ).

Table 6

Energy $\left(E_{\mathrm{A}}\right)$ absorbed by a plant cell of the sufrace $600 \mu \mathrm{m}^{2}$. One layer of the chloroplasts in state II occupies $90 \%$ of the illuminated wall sufrace. The chloroplasts do not change their position but only the conformation state $\mathrm{E}_{0}=100$ units $/ \mu \mathrm{m}^{2}=60,000$ units

\begin{tabular}{|l|c|c|c|c|}
\hline State & $\begin{array}{c}\% \text { of sufrace } \\
\text { occupied by } \\
\text { chloroplasts }\end{array}$ & $\begin{array}{c}\text { Sufrace } \\
\text { occupied by } \\
\text { chloroplasts } \\
\text { in } \mu \mathrm{m}^{2}\end{array}$ & $\begin{array}{c}\text { Energy } \\
\text { absorbed } \\
\mathrm{E}_{\text {A }} \text { (unit) }\end{array}$ & $\begin{array}{c}\text { Per cent of } \\
\text { absorbed } \\
\text { energy }\end{array}$ \\
\hline I & 69.16 & 415 & 18849 & 31.42 \\
II & 90 & 540 & 20250 & 33.75 \\
III & 59.96 & 360 & 17997 & 29.98 \\
IV & 53.54 & 321 & 16797 & 27.98 \\
\hline
\end{tabular}




\section{DISCUSSION}

The calculations of absorption carried out in the present investigation were based on three assumptions. It was presumed that the local thickness of the chloroplast changes as though the chloroplast were an ellipsoid of revolution. Measurements of the actual thickness of the chloroplasts, based on the analysis of microphotographs as well as on evaluation of local absorption, showed this assumption to approximate the actual state. A higher degree of conformity of theoretical with real thickness results from direot measurements, slightly greater discrepancies being ascertained at measurements of local absorption. Horwever, this last method is undoubtedly burdened with a greater error owing to the lens effect and to possible occurrence of slight nonhomogeneity of the chloroplasts. In principle, essential deviations of the actual from the assumed shape are only encountered in the peripheral area of the chloroplast, where its thickness slightly exceeds that estimated in the ellipsoid of revolution of identical dimensions.

The second assumption, of the constant amount of pigments in the chloroplasts may be regarded as valid on the basis of numerous data from which it follows that the amount of pigments in the outgrown leaf, unless exposed to drastically high, damaging light intensities, remains unchanged.

The third assumption, of the uniform pigment distribution in the chloroplast is false but necessary to adopt on account of its being impossible to establish precisely the local distribution of pigments. Such simplification should not affect significantly the results of calculations in the case of the Funaria chloroplasts whose grana are not very strongly developed.

The result of the measurements of extinction in the central part of the chloroplast coincided with the literature data. The absorption of red light in its maximum, for large chromatophores of the algae ranged between 60 and $70 \%$ (Albes, Knorr, 1937) and between 50 and $70 \%$ (D r a w e r t, 1966). The absorption value for the chloroplast of Chlorella was determined as approximating $25 \%$ ( $\mathrm{Th}$ o m a s et al., 1970), and for the chloroplasts of the vascular plant Zamioculus as $40-50 \%$ ( $\mathrm{S}$ o r a $\mathrm{n}$ et al., 1973). The mean red light absorption in the centre of the Funaria chloroplàst adapted to darkness, which was established in the present investigations as amounting to $54 \%$, does not depart from the above data.

As follows from the calculations, the mean absorption of the radiation incident on a unit of chloroplast surface declines with enlargement of the surface. This results from a decreased thickness of the absorbing layer during the "flattening" of the ellipsoid. This correlation for the means of three natural coefficients of absorption is presented in Fig. 3. On the other hand, the enlargement of the chloroplast surface brings about a rapid increase in the amount of total energy absorbed by it (Fig. 4). Changes in the volume of the chloroplast whose surface remains unchan- 
ged do not affect the mean intensity of absorbed light or, consequently, the total value of the energy absorbed by the chloroplast. According to the assumptions, a change in the chloroplast thickness (d) causes an inversely proportional change in the product $\alpha$ c (i.e. in pigment concentration). In the formulae (2) and (3) these values occur exclusively as the product $\alpha \mathrm{cd}$, so changes in them brought on by an alteration in the volume of the ellipsoid become compensated.

Among the states of conformation under study, the chloroplast in the flattened state absorbs most energy, while the least amount of it is absorbed by the strongly contracted chloroplast. This is in agreement with the tendency of the cell to maximise utilization of the radiation of low intensity and to reduce the amount of absorbed energy under very intense illumination. A similar tendency is manifested by chloroplast translocation. Taking into account the sieve effect ( $\mathrm{R}$ a binowitch, 1951; B r it z, 1975) i.e. considering the fact that part of the light incident on the cell does not reach the chloroplasts at all but passes by them, the authors obtained the model shown in Table 6. Alterations in the energy absorbed by one layer of the chloroplasts which do not undergo translocation but only structural changes, are significant but not very extensive. For the radiation intensely absorbed by the Funaria chloroplasts these changes can be estimated as equal to ca. $4 \%$. Y a m a shit a et al. (1968) have determined the maximum change in absorption associated with the conformation state in a suspension of chloroplasts as equal to $2,5 \%$. Thus, the orientation of the chloroplasts in relation to the direction of incident light causes some but insignificant increase in these alterations. Considerable changes in absorption (ranging from 15 to $20 \%$ ) recorded after the leaves had been transferred from the conditions of low to those of high light intensity, or vice versa (Zurzycki, 1961; Inoue, Shibata, 1973; Pfau et al., 1974), should therefore be mainly associated with chloroplast translocation in the cell.

\section{REFERENCES}

Albes V. M., Knor H. V. 1937. Absorption spectra of single chloroplasts in living cells in the region from 664 to 704 um. Plant Physiol. 12: 833 - 843.

- B i e b 1 R., 1954. Lichttransmission und Chloroplastenbewegung. Flora 141: 163 - 177. Britz S. J., 1975., A model system to simulate chloroplast movement and accompanging transmiance changes in Ulva. Ann. Rep. Carnegie Inst. of Washington $795-803$.

Drawert H., 1966. Der mikrospektralphotometrische Nachweis von Chlorophyll $\mathrm{b}$ in Closterium und einigen Mesotaeniaceen. Ber. dtsch. bot. Ges. 79: 403-406.

$\mathrm{He}$ ber U., 1969. Conformational changes of chloroplasts induced by illumination of leaves in vivo. Biochem. Biophys. Acta 180: $302-319$.

I n o u e Y., S hi b a t a K., 1973. Light-induced chloroplasts rearrangements and their action spectra as measured by absorption spectrophotometry. Planta 114: $341-358$. 
It oh M., Izawa S., Shibata K., 1963. Shrinkage of whole chloroplasts upon illumination. Biochem. Biophys. Acta 66: $319-327$.

Le ch owski Z., 1970. Some aspects of chloroplast movement in leaves of terrestial plants. Acta Soc. Bot. Pol. 39: $453-468$.

L e c how s ki Z., 1973. The action spectrum in chloroplast translocation in multilayer leaf cells. Acta Soc. Bot. Pol. 42: $461-472$.

P a cker L., B ernard A. C., De a m er P. W., 1967. Ultrastructural and photometric evidence for light-induced changes in chloroplast structure in vivo. Plant Physiol. 42: $283-293$.

Pfa u J., Throm G., Nultsch W., 1974. Recording microphotometer for determination of light induced chromatophore movements in brown algae. Z. Pflanzenphysiol. 71: $242-260$.

R a binovitch I. 1951. Photosynthesis and related processes. vol. 2. Willey Interscience. New York.

Soran V., Smith B., Vintila R., 1973. Absorption spectra of Zamioculus Boivinii chloroplasts recorded in vivo and after isolation by microspectrophotometric method. Z. Pflanzenphysiol. 69: $100-108$.

Thomas J., Phonilko G. P., Tatake V. G., Gopal-A yebger A. R., 1970. Microspectrophotometric studies on the pigments in vivo of single algal cells. 1 . Pigments of Chlorella pyrenoidosa. Photochem. Photobiol. 11: 85 - 92.

Y a mashita K., I to h M., Shibat a K., 1968. Light-absorption and light-scattering changes during shrinkage and swelling of chloroplasts. Biochem. Biophys. Acta 162: 610 - 613 .

Zurzycki J., 1953. Arrangement of chloroplasts and light absorption in plant cell. Acta Soc. Bot. Pol. 22: 299 - 318.

Zurzycki J., 1961. The influence of chloroplast displacements on the optical properties of leaves. Acta Soc. Bot. Pol. 30: $503-527$.

$\mathrm{Zurzycki}$ J., 1974. The effect of blue and red radiation on the volume changes of Funaria chloroplasts in vivo. Photosynthetica 8: $302-319$.

Author's address:

Prof. dr J. Zurzycki

Dr. H. Gabryś

Department of Plant Physiology

Institute of Molecular Biology

Jagellonian University

31-001 Kraków, Grodzka 53

Poland

\section{Zmiany absorpcji światła w chloroplaście związane ze zmianami strukturalnymi}

Streszczenie

Określono zmiany absorpcji światła w pojedynczym chloroplaście i w warstwie chloroplastów związane z zmianami strukturalnymi chloroplastów wywołanymi różnymi warunkami oświetlenia. Wyprowadzono teoretyczne wzory na całkowitą ilośc 
pochłoniętej energii $\left(\mathrm{E}_{\mathrm{A}}\right)$ i średni procent absorpcji $\left(\overline{\mathrm{I}}_{\mathrm{A}}\right)$ dla bryły o kształcie elipso:dy obrotowej.

Wykazano że chloroplasty Funaria przyjęte za obiekty modelowe można traktować jako posiadające kształt elipsoidy obrotowej. Dla tych chloroplastów określono zmiany w absorpcji związane ze zmianą ich kształtu stwierdzając, iż największą ilość energii świetlnej pochłaniają chloroplasty w stanie maksymalnie rozpłaszczonym. Największe zmiany absorpcji w jednej warstwie chloroplastów wywołane ich przekształceniami konformacyjnymi określono na około $4^{\%} \%$. 